\title{
EDITORIAL: Feminist Fictions
}

The untimely death of Angela Carter was a poignant way to be reminded of the flourishing of feminist writing over the past two decades. In the English-speaking world, at least, feminist presses still manage to survive the economic winter and feminist writing in a myriad of genres is finding its way to other publishers and to the theatre and television as well.

The articles on 'Feminist Fictions' in this issue arise out of a collaboration between Feminist Review and the women members of the editorial board of the German journal Das Argument. Some of us met with Frigga Haug and Kornelia Hauser over a meal in London. We talked about possibilities for joint projects and Frigga and Kornelia told us of their interest in popular writing as a vehicle for feminist ideas. In a period when the women's movement has no clear public presence, many women are meeting feminist ideas through reading novels and watching television serials. The Argument publishing house has been issuing German translations of American popular feminist novels - by Marge Piercy, Sarah Schulman and Barbara Wilson. We decided to produce parallel issues of our two journals, with a set of articles on this theme that would appear in English and German at around the same time.

The articles here have a variety of approaches to the topic. Frigga and Kornelia's are part of a coherent theoretical project, which is spelled out at the beginning of Frigga's article. The others are quite different and indeed the German women would probably be quite critical of the rather pessimistic conclusion that Joke Hermes draws about the political potential of lesbian romance fiction. What they have in common, perhaps, is that they focus on the feminist content of the books that they consider, rather than being concerned with literary criticism or literary theory of the sort that Feminist Review has more often been engaged with. We hope that articles in this issue will raise questions about popular genres as a potential site for a feminist contribution. Can feminism really undermine the most conservative genres like fairy stories or romance fiction? We leave readers to draw their own conclusions - and perhaps continue the debate.

Feminist Review No 42, Autumn 1992 